\title{
THE EFFECT OF BUSINESS PROCESS REENGINEERING FACTORS ON ORGANISATIONAL PERFORMANCE
}

\author{
YASER ALMANSOUR \\ ATEF ALADWAN \\ MUSA ALSAUDI \\ Al Balqa Applied University \\ Amman, Jordan
}

\begin{abstract}
This study empirically investigated the effect of business process reengineering factors on organisational performance in the Saudi context. A quantitative approach was employed whereby this study focused on Riyadh factory for re-refining oils employees. A total of 110 useable questionnaires were used in the statistical analysis. Business process reengineering factors that were investigated include the major improvements after business process reengineering, the major changes after implementation of business process reengineering and the personal gain after business reengineering process. The results showed that the only two factors out of the three do affect organisational performance in Riyadh factory for re-refining oils employees namely the major improvements after business process reengineering and the major changes after implementation of business process reengineering.
\end{abstract}

Keywords: Business process reengineering, organizations performance, personal gain.

Received: 06/09/2015 Revise: 06/11/2016 Accepted: 16/11/2016 Publish: 15/12/2016

\section{Introduction}

The main objective of any organisation is to improve its performance by different ways. One of an important tool is re-engineering the business process which could be made to redesign the current business practices components into another more efficient form. In the world of competition, re-engineering the business process is the key factor for organisational success or performance. Johnson, Scholes and Whittington (2006) stated that the environment is changing and 
thus it demands as well as makes it an imperative for organisations to improve its business performance.

The tools, methods and approaches can be developed and restructured in several organisations to increase business success by making the organisations more effective and efficient. This changing and restructuring is called business process reengineering (Gouranourimi, 2012).

Chase, Jacobs, Aquilano and Agarwal (2006) defined business process reengineering as the essential rethinking and radical redesign of business processes to achieve dramatic improvements in critical, contemporary measures of performance such as cost, quality, service, speed, profit, market share, and sales volumes. Moreover, Al-Mashari and Zairi (2001) proposed that the main objectives of business reengineering are to transport and distribute more value all the way to the customer through rethinking of existing processes, and using technology to improve data dissemination and decision making. Consequently, for business process reengineering to be carefully planned successfully, performance has to be considered against the set objectives for business process reengineering to have a positive and significant effect on any organisation (Gouranourimi, 2012).

Similarly, Randle (1995) documented that business process reengineering has a significant association with the performance of organisations by improving the profit, sales volumes, market shares, speed, customer satisfaction, accuracy, cost, effectiveness, and efficiency. The implementation of booming business process reengineering initiatives has led to the need for improvement of a useful as well as realistic conceptual model which spearheads the process of improvement, growth and change.

Furthermore, the implementation of a successfully business process reengineering initiative will significantly affect the organisational performance, which could be evaluated and assessed along the dimensions of turnaround time an organisation takes to bring and transformed services, the quality of products, reducing the cost, technology improvement, and gaining more revenues (Chase et al., 2006; Al-Mashari \& Zairi, 2001).

Meanwhile, Hall, Rosenthal, and Wade (1993) documented that even though business process reengineering is gaining in popularity, the effort of reengineering initiatives fail to achieve their goals, ranging between 60 to $80 \%$. This failure rate could be because of the challenging 
endeavours as well as the complexity in the implementation process, which leads to less significant development of organisational performance. Therefore, it is important to determine the business process reengineering factors that influence or effect organisational performance.

The impact of business process reengineering on organisational performance has been studied in different countries and the resulting effect has been documented (Chase et al.,2006; Al-Mashari \& Zairi, 2001). These findings may be differ if applied in Saudi organisations due to the different of environment. More specifically, the aim of this study was to investigate the effect of business process reengineering on organisational performance in the Saudi context.

\section{Literature Review}

The main aim of business process reengineering is to build business organisations much more competitively by shortening product development cycles, developing quality, as well as reducing the cost (Grover, Jeong, Kettinger, \& Teng 1993; Chase et al., 2006; AlMashari \& Zairi, 2001; Chase, Jacobs, Aquilano and Agarwal, 2004; Gouranourimi, 2012).

Sidikat and Ayanda (2008) researched the effect of business process reengineering on banking performance. A primary data instrument was distributed to bank employees and the data were analysed using SPSS. From regression analysis, the results showed that business process reengineering factors play an important role to improve as well as develop bank performance.

Meanwhile in a study conducted in Nigeria, Sidikat and Ayanda (2008) investigated the effect assessment of business process reengineering on organisational performance in Nigerian banks. By collecting and analysing primary data, the results indicated that several factors of business process reengineering plays a significant role in increasing banks performance. These factors are service quality (SQ), and innovative and strategic change (I \& SC), which positively affect banking institutional performance directly. The authors declared that these significant factors are related to the success of an organisation.

In a similar vein in China, the effect of business process reengineering on organisational performance was investigated by $\mathrm{He}$ (2009). Primary data were gathered from employees by using two questions 
namely: How do Chinese business executives view benefits, critical success factors, and major obstacles of BPR implementation? What are the managerial implications of BPR in China? Based on the statistical results, the business process reengineering factors have a significant effect on organisational performance. However, the implementation of business process reengineering has been uneven among various types of business sectors and ownerships.

Furthermore, Magutu, Nyamwange and Kaptoge (2010) conducted a research on business process reengineering intended for competitive benefit. Primary data were collected from the employees of the Wrigley Company. The research investigated the competitive measure and business process reengineering implementation key success factors. The results showed that if the company implements business process reengineering, the company gains competitiveness. In other words, there is a positive relationship between implementing successful factors of business process reengineering and gaining competitiveness in the company.

Similarly, Setegn, Ensermu, and Moorthy (2013) conducted a research on investigating the impact of business process reengineering on organisational performance of the Bureau Finance and Economic Development (BOFED). Primary data were gathered and a Likert scale was used for analyses to achieve the research objective. Based on the analysis, the results showed that the customers of (BOFED) were satisfied with speed of service, delivery quality of service, and cycle time.

Meanwhile in Pakistan, Habib (2013) studied the critical success and failure factors of business process reengineering. He employed an instrument to gather primary data to achieve the objective of his study. Based on his results, it was documented that the firms are transferring from a product centred approach to customer oriented approach. Hence, the firms are trying to make the customers more satisfied in the products prepared by the companies. He declared that bringing change into an organisation is very difficult and very demanding.

Aside in Iran, Mohammad and Elaheh (2014) conducted a research on the impact of business process reengineering factors on organisational agility in ports and maritime organisations. A primary data were collected and path analysis was employed to investigate the impact of business process reengineering on organisational performance. The results showed that leadership and empowerment factors have significant impact on organizational agility over the other variables studied. 
Meanwhile in Nigeria, a conceptual research on studying business process reengineering and organisational performance was conducted by Eke and Achilike (2014). The main objective of this research was to analyse BPR in relation to organisational performance in the Nigerian banking sector. The authors declared that the business process reengineering can raise or increase the quality as well as the productivity of the organisation.

The analyses of some of the literature review on the status of the impact of business process reengineering factors on organisational performance were carried out by applying a qualitative method, which provided a sufficient understanding of the context within which the issue can be studied and analysed. Based on the past previous study, both qualitative and quantitative, it is obvious to declare that there has been no study investigating on the impact of business process reengineering factors on organisational performance in Saudi Arabia. Therefore, the aim of this study was to investigate the effect of business process reengineering factors on organizational performance in Riyadh factory for re-refining oils.

\section{Theoretical Framework}

This study investigated the effect business process reengineering factors have on organisational performance in Riyadh factory for re-refining oils. Therefore, Figure 1 illustrates the theoretical framework of this study.

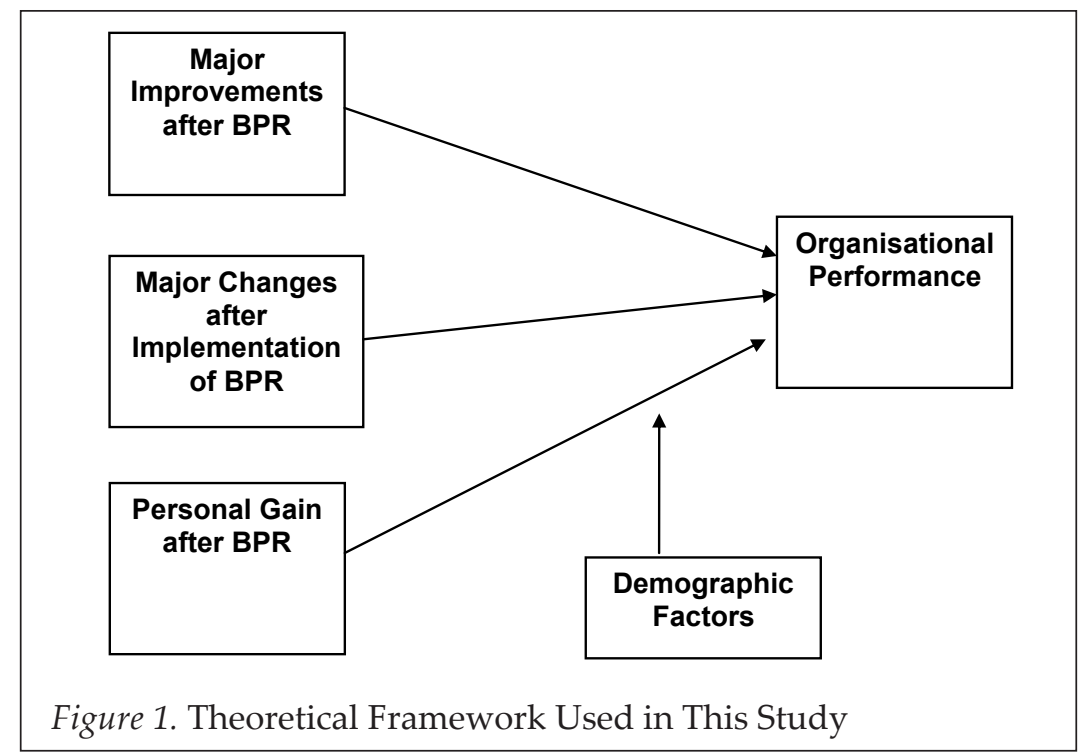




\section{Sample and Procedure}

In order to investigate the effect business process reengineering factors have on organisational performance, a quantitative approach was used. This study focused on employees of a Riyadh factory for re-refining oils, where a total of 120 questionnaires were distributed. The selection of the respondent was based on the intended comprehensive sampling method. Respondents were given a week to answer the questionnaires. In all, a total of 110 useable questionnaires were used in the statistical analysis.

\section{Measurement of the Variables}

The independent variable of this study is the business process reengineering factors namely the major improvements after business process reengineering, major changes after implementation of business process reengineering, and personal gain after business process reengineering. These factors were employed based on a developed instrument by Mansar and Reijers (2007), where the factors are contained in 33 items. The independent variables and theirs measurements are illustrated in the following sections:

1. Respondents expectation on major improvements after BPR

- Full implementation and integration of reengineered processes into the organisation.

- Evaluate success of reengineered effort against the performance objectives.

- $\quad$ Recognise the need for change.

- Evaluate and document current processes to uncover bottlenecks.

- $\quad$ Form reengineering project team.

- $\quad$ Monitor progress.

- Develop a plan/vision for the change.

- $\quad$ Estimate the scope of the change and resource requirement needs.

- $\quad$ Select the business processes to be redesigned.

- Establish baseline and benchmark to gauge future improvements.

- Undertake pilot study.

2. Respondents expectation on major changes after implementation of BPR

- $\quad$ The customer / stakeholder was involved in the change process. 
- Managers are anxious about losing their authority after the changes.

- $\quad$ There are training and/or education programmes to update employee skills.

- The re-engineering effort is straight forward and practical.

- $\quad$ Teamwork is the typical way of solving problems.

- There is frequent communication between the project team and users.

- There exist performance improvement goals for processes.

- Top management has realistic expectation of the project.

- There is adequate alignment of IT infrastructure and BPR strategy.

- $\quad$ There is effective use of consultants.

- $\quad$ Employees are empowered to make decisions.

3. Personal gain after BPR

- The number of departments, groups, and persons involved in a business process has been minimised.

- $\quad$ Unnecessary tasks have been eliminated from business process.

- Controls have been moved towards the customer.

- Geographically dispersed resources have been centralised.

- The organisation is able to achieve its strategic objectives.

- New processes have been created by combining small composite tasks.

- $\quad$ Physical constraints have been elevated in business processes by applying new technology.

- $\quad$ Tasks have been automated.

- Contact between the customer and third parties have been reduced.

- $\quad$ Employees have been empowered by being given more decision making authority.

- $\quad$ Customer complaints have reduced.

The dependent variable of this study was organisational performance. The organisational performance questionnaires was employed based on a developed instrument by Hassan, Mukhtar, Qureshi, and Sharif (2012), where the questionnaire contains 11 items. All items were based on the five-point Likert scale ranging from 1 for strongly disagree to 5 
for strongly agree. The dependent variable and its measurements are illustrated as below:

4. Measurement to evaluate performance

- Reduction in cycle time.

- Reduction in customer complaint.

- Reduction in defect rate.

- $\quad$ Reduction in delivery time.

- Reduction in rework.

- Increase in total sales.

- Increase in market share.

- Increase in net profit.

- Increase in employees attitude towards quality.

- Increase in quality of product/services provided by one department to another.

- Increase in communication between departments.

In order to figure out the impact of business process reengineering factors on organisational performance in Saudi Arabia, regression analysis was performed. Before proceeding to carry out the multiple regression analysis, this study has tested the assumptions of multiple linear regressions which justify the use of linear regression models for the purposes of examining the business process reengineering factors that influence organisational performance to be acceptable.

\section{The Results and Hypotheses Testing}

\section{Respondent Profile}

The respondent profiles is shown in Table 1. It can be observed that there were $110(100 \%)$ male respondents and $0(0 \%)$ female respondents; this was due to the culture of the country. In terms of the age of the respondents, the results showed that the 60 respondents were aged between $20<30$ years $(55 \%)$, 35 were aged between 30 $<40$ years $(32 \%), 10$ respondents were aged between $40<50$ years $(9 \%)$, and five respondents were more than 50 years old (5\%). Finally, in terms of education, it was observed that most of the respondents were educated: 47 respondents have secondary school certificates and 15 respondents $(14 \%)$ have a diploma, while 43 respondents hold a bachelor degree $(39 \%)$. Furthermore, there were three respondents who hold a degree in engineering (3\%), and two respondents who hold postgraduate degrees $(2 \%)$. 
IJMS 23 (2), 65-81 (2016)

Table 1

Profile of Respondents

\begin{tabular}{clrc}
\hline Demographic & Category & n & Percentage \\
\hline Gender & Male & 110 & $100 \%$ \\
& Female & 0 & $0 \%$ \\
& Total & 110 & $100 \%$ \\
\hline \multirow{2}{*}{ Age } & $20<30$ years & 60 & $55 \%$ \\
& $30<40$ years & 35 & $32 \%$ \\
& $40<50$ years & 10 & $9 \%$ \\
& $>50$ years & 5 & $5 \%$ \\
& Total & 110 & $100 \%$ \\
& Secondary School & 47 & $43 \%$ \\
& Diploma Degree & 15 & $14 \%$ \\
& Bachelor Degree & 43 & $39 \%$ \\
& Engineer & 3 & $3 \%$ \\
& Postgraduate & 2 & $2 \%$ \\
& Total & 110 & $100 \%$ \\
\hline
\end{tabular}

\section{Descriptive Statistics}

Descriptive statistics are used to describe the basic features of the data in a study. Table 2 illustrates the criteria for understanding the mean scores for satisfaction level.

Table 2

The Criteria for Understanding the Mean Scores of Satisfaction Level

\begin{tabular}{lcc}
\hline & Mean Score & Level of Satisfaction \\
\hline $\mathbf{1}$ & $1.00-1.80$ & Strongly Disagree \\
$\mathbf{2}$ & $1.81-2.60$ & Disagree \\
$\mathbf{3}$ & $2.61-3.40$ & Neutral \\
$\mathbf{4}$ & $3.41-4.20$ & Agree \\
$\mathbf{5}$ & $4.21-5.00$ & Strongly Agree \\
\hline
\end{tabular}


IJMS 23 (2), 65-81 (2016)

As a result, the descriptive statistics can be analysed. Table 3 illustrates the descriptive statistics for all items used in this study.

\section{Table 3}

Descriptive Statistics for All Items Used in the Study

\begin{tabular}{|c|c|c|c|c|}
\hline $\mathrm{N}$ & Items & Mean & $\begin{array}{c}\text { Std. } \\
\text { Deviation }\end{array}$ & Meaning \\
\hline 1 & $\begin{array}{l}\text { Organisational top management } \\
\text { (senior executives and } \\
\text { supervisors) views improvement } \\
\text { in quality as a way to increase } \\
\text { profits }\end{array}$ & 4.063 & .80454 & Agree \\
\hline 2 & $\begin{array}{l}\text { Organisational top management } \\
\text { has objectives for quality } \\
\text { performance }\end{array}$ & 4.081 & .59249 & Agree \\
\hline 3 & $\begin{array}{l}\text { Organisational top management } \\
\text { is evaluated for quality } \\
\text { performance }\end{array}$ & 4.072 & .60136 & Agree \\
\hline 4 & $\begin{array}{l}\text { Our firm has an effective } \\
\text { performance measurement } \\
\text { system to track overall } \\
\text { organisational performance }\end{array}$ & 4.054 & .71467 & Agree \\
\hline 5 & $\begin{array}{l}\text { Quality data (error rates, defect } \\
\text { rates, scrap, defects, rework rates, } \\
\text { cost of quality, etc.) are available }\end{array}$ & 4.045 & .54833 & Agree \\
\hline 6 & $\begin{array}{l}\text { Timely firm performance data are } \\
\text { always available }\end{array}$ & 4.009 & .76020 & Agree \\
\hline 7 & $\begin{array}{l}\text { We design processes in our firm } \\
\text { to be "mistake-proof" to minimise } \\
\text { the changes of errors }\end{array}$ & 4.118 & .57040 & Agree \\
\hline 8 & $\begin{array}{l}\text { We make extensive use of } \\
\text { statistical techniques to reduce } \\
\text { variation in processes }\end{array}$ & 4.109 & .73379 & Agree \\
\hline 9 & $\begin{array}{l}\text { We give clear, comprehensive, } \\
\text { and standardised documentation } \\
\text { about work methods and process } \\
\text { instructions to employees }\end{array}$ & 4.000 & .70386 & Agree \\
\hline
\end{tabular}


IJMS 23 (2), 65-81 (2016)

\begin{tabular}{|c|c|c|c|c|}
\hline $\mathrm{N}$ & Items & Mean & $\begin{array}{c}\text { Std. } \\
\text { Deviation }\end{array}$ & Meaning \\
\hline 10 & $\begin{array}{l}\text { A large amount of the equipment } \\
\text { on the shop floor is currently } \\
\text { under statistical process control }\end{array}$ & 4.054 & .60330 & Agree \\
\hline \multirow[t]{2}{*}{11} & $\begin{array}{l}\text { Training in advanced statistical } \\
\text { techniques is given to the } \\
\text { employees who need training }\end{array}$ & 3.990 & .69725 & Agree \\
\hline & $\begin{array}{c}\text { Total / Major Improvements } \\
\text { after BPR }\end{array}$ & 4.045 & 0.6664 & Agree \\
\hline 1 & $\begin{array}{l}\text { Our employees possess sufficient } \\
\text { knowledge of the basic aspects of } \\
\text { our sector }\end{array}$ & 4.072 & .67333 & Agree \\
\hline 2 & $\begin{array}{l}\text { Our employees understand the } \\
\text { basic processes used to make our } \\
\text { products/services }\end{array}$ & 4.081 & 62269 & Agree \\
\hline 3 & $\begin{array}{l}\text { Managers and supervisors } \\
\text { participate in specialist training }\end{array}$ & 4.181 & .62342 & Agree \\
\hline 4 & $\begin{array}{l}\text { Resources are available for } \\
\text { employee quality training in our } \\
\text { firm }\end{array}$ & 4.163 & .59858 & Agree \\
\hline 5 & $\begin{array}{l}\text { Our suppliers have an effective } \\
\text { system to ensure quality of their } \\
\text { products and/or services }\end{array}$ & 4.154 & .60860 & Agree \\
\hline 6 & $\begin{array}{l}\text { We emphasise on quality and } \\
\text { delivery performance rather than } \\
\text { price in selecting suppliers }\end{array}$ & 4.100 & .63463 & Agree \\
\hline 7 & $\begin{array}{l}\text { Our suppliers are involved in our } \\
\text { quality training }\end{array}$ & 4.118 & 65988 & Agree \\
\hline 8 & $\begin{array}{l}\text { We work closely with suppliers to } \\
\text { improve each other's processes }\end{array}$ & 4.136 & .58226 & Agree \\
\hline 9 & $\begin{array}{l}\text { Our suppliers are actively } \\
\text { involved in our new product } \\
\text { development process }\end{array}$ & 4.163 & .56710 & Agree \\
\hline 10 & $\begin{array}{l}\text { We frequently are in close contact } \\
\text { with our customers }\end{array}$ & 4.054 & .67507 & Agree \\
\hline
\end{tabular}

(continued) 
IJMS 23 (2), 65-81 (2016)

\begin{tabular}{|c|c|c|c|c|}
\hline $\mathrm{N}$ & Items & Mean & $\begin{array}{c}\text { Std. } \\
\text { Deviation }\end{array}$ & Meaning \\
\hline \multirow[t]{2}{*}{11} & $\begin{array}{l}\text { We actively and regularly seek } \\
\text { customer inputs to identify their } \\
\text { needs and expectations }\end{array}$ & 4.136 & .67017 & Agree \\
\hline & $\begin{array}{l}\text { Total / Major Changes after } \\
\text { Implementation of BPR }\end{array}$ & 4.124 & 0.6287 & Agree \\
\hline 1 & $\begin{array}{l}\text { We inform customers' current and } \\
\text { future needs and expectations to } \\
\text { our employees effectively }\end{array}$ & 4.200 & .68804 & Agree \\
\hline 2 & $\begin{array}{l}\text { Our customers give us feedback } \\
\text { on quality and delivery } \\
\text { performance }\end{array}$ & 4.263 & .61595 & $\begin{array}{c}\text { Strongly } \\
\text { Agree }\end{array}$ \\
\hline 3 & $\begin{array}{l}\text { Customer complaints are used as } \\
\text { input to improve our processes }\end{array}$ & 4.227 & .48195 & $\begin{array}{l}\text { Strongly } \\
\text { Agree }\end{array}$ \\
\hline 4 & $\begin{array}{l}\text { We measure customer satisfaction } \\
\text { systematically and regularly }\end{array}$ & 4.181 & .54490 & Agree \\
\hline 5 & $\begin{array}{l}\text { We have a mission statement } \\
\text { which has been communicated } \\
\text { throughout the firm and is } \\
\text { supported by our employees }\end{array}$ & 4.200 & .53843 & Agree \\
\hline 6 & $\begin{array}{l}\text { We develop and implement } \\
\text { our strategies and plans based } \\
\text { on data concerning customers' } \\
\text { requirements and the firm's } \\
\text { capabilities }\end{array}$ & 4.236 & .46781 & $\begin{array}{l}\text { Strongly } \\
\text { Agree }\end{array}$ \\
\hline 7 & $\begin{array}{l}\text { The management communicates } \\
\text { its strategy and objectives to the } \\
\text { staff }\end{array}$ & 4.281 & .45194 & $\begin{array}{l}\text { Strongly } \\
\text { Agree }\end{array}$ \\
\hline 8 & $\begin{array}{l}\text { Customers' needs are taken } \\
\text { into account when establishing } \\
\text { objectives }\end{array}$ & 4.272 & .60440 & $\begin{array}{l}\text { Strongly } \\
\text { Agree }\end{array}$ \\
\hline 9 & $\begin{array}{l}\text { Our quality strategies affect } \\
\text { all organisational areas and } \\
\text { managerial activities }\end{array}$ & 4.263 & .55318 & $\begin{array}{l}\text { Strongly } \\
\text { Agree }\end{array}$ \\
\hline 10 & $\begin{array}{l}\text { Quality of our products/services } \\
\text { is high }\end{array}$ & 4.172 & .55618 & Agree \\
\hline
\end{tabular}

(continued) 
IJMS 23 (2), 65-81 (2016)

\begin{tabular}{|c|c|c|c|c|}
\hline $\mathrm{N}$ & Items & Mean & $\begin{array}{c}\text { Std. } \\
\text { Deviation }\end{array}$ & Meaning \\
\hline \multirow[t]{2}{*}{11} & $\begin{array}{l}\text { Reliability of our products/ } \\
\text { services is high }\end{array}$ & 4.227 & .48195 & $\begin{array}{l}\text { Strongly } \\
\text { Agree }\end{array}$ \\
\hline & Total / Personal Gain after BPR & 4.229 & 0.5441 & $\begin{array}{l}\text { Strongly } \\
\text { Agree }\end{array}$ \\
\hline 1 & $\begin{array}{l}\text { We deliver our products/services } \\
\text { on time to customers }\end{array}$ & 4.209 & .56007 & $\begin{array}{l}\text { Strongly } \\
\text { Agree }\end{array}$ \\
\hline 2 & $\begin{array}{l}\text { Purchase material turnover is } \\
\text { high in our firm }\end{array}$ & 4.190 & .55015 & Agree \\
\hline 3 & $\begin{array}{l}\text { Total inventory turnover is high } \\
\text { in our firm }\end{array}$ & 4.218 & .53126 & $\begin{array}{l}\text { Strongly } \\
\text { Agree }\end{array}$ \\
\hline 4 & $\begin{array}{l}\text { Our employees' organisational } \\
\text { commitment is high }\end{array}$ & 4.145 & .50386 & Agree \\
\hline 5 & $\begin{array}{l}\text { Our employees' job performance } \\
\text { is high }\end{array}$ & 4.145 & .48531 & Agree \\
\hline 6 & $\begin{array}{l}\text { Our employees' absenteeism is } \\
\text { low }\end{array}$ & 4.072 & .44328 & Agree \\
\hline 7 & Our employees' morale is high [ & 4.227 & .53602 & $\begin{array}{l}\text { Strongly } \\
\text { Agree }\end{array}$ \\
\hline 8 & $\begin{array}{l}\text { Our employees' turnover rate is } \\
\text { low }\end{array}$ & 4.209 & .50856 & $\begin{array}{l}\text { Strongly } \\
\text { Agree }\end{array}$ \\
\hline 9 & $\begin{array}{l}\text { The number of successful new } \\
\text { product/service introductions of } \\
\text { our firm is high }\end{array}$ & 4.118 & .60171 & Agree \\
\hline 10 & $\begin{array}{l}\text { The use of latest technological } \\
\text { innovations in our new product } \\
\text { is high }\end{array}$ & 4.190 & .64246 & Agree \\
\hline \multirow[t]{2}{*}{11} & $\begin{array}{l}\text { The technological competitiveness } \\
\text { of our firm is high }\end{array}$ & 4.163 & .64292 & Agree \\
\hline & $\begin{array}{l}\text { Total / Organisational } \\
\text { Performance }\end{array}$ & 4.171 & 0.5460 & Agree \\
\hline
\end{tabular}

Table 3 shows the descriptive statistics (mean as well as standard deviation) for all items used in the study. It can be seen that the overall satisfaction of the major improvements after business process 
reengineering was at the satisfied level with me mean score of 4.045 and standard deviation of 0.6664 . Furthermore, the major changes after implementation of business process reengineering was at satisfied level with mean score of 4.124 and standard deviation of 0.6287 .

The overall mean for the personal gain after business process reengineering was at strongly agree level which recorded a value of 4.229 and standard deviation of 0.5441 . Moreover, the overall mean for the organisational performance was at the agree level which recorded a value of 4.171 and standard deviation of 0.5460 .

\section{Business Process Reengineering Factors Influencing Organisational Performance}

In order to investigate the influence of business process reengineering factors on organisational performance, regression analysis was employed. Table 4 illustrates the influence of the major improvements after business process reengineering, the major changes after implementation of business process reengineering and the personal gain after business process reengineering on organisational performance.

Table 4

The Influence of Business Process Reengineering Factors on Organisational Performance

\begin{tabular}{|c|c|c|c|c|c|c|c|}
\hline \multirow[b]{2}{*}{ Model } & \multicolumn{2}{|c|}{$\begin{array}{l}\text { Unstandardised } \\
\text { Coefficients }\end{array}$} & \multirow{2}{*}{$\begin{array}{c}\text { Standardised } \\
\text { Coefficients } \\
\text { Beta }\end{array}$} & \multirow[b]{2}{*}{$\mathrm{t}$} & \multirow[b]{2}{*}{ Sig. } & \multicolumn{2}{|c|}{$\begin{array}{l}\text { Collinearity } \\
\text { Statistics }\end{array}$} \\
\hline & B & Std. Error & & & & Tolerance & VIF \\
\hline (Constant) & 3.906 & .447 & & 8.730 & .000 & & \\
\hline $\begin{array}{l}\text { Major } \\
\text { Improvements }\end{array}$ & .214 & .075 & .250 & 2.838 & .005 & .991 & 1.009 \\
\hline Major Changes & -.231 & .054 & -.383 & -4.302 & .000 & .968 & 1.033 \\
\hline Personal Gain & .050 & .076 & .058 & .652 & .516 & .976 & 1.024 \\
\hline $\mathrm{R}^{2}$ & 0.188 & & & & & & \\
\hline VIF Problem & No & & & & & & \\
\hline Hetroscadicity & No & & & & & & \\
\hline
\end{tabular}

The results in the Table 4 above showed that the coefficient of determinations $R^{2}$ value was 0.188 . This implied that on average the 
variability in the influenced construct for this study can explain $18.8 \%$ of the variability in the organisational performance.

The results showed that there is a significant effect of major improvements after business process reengineering and the major changes after implementation of business process reengineering on organisational performance, which recorded a significant value of 0.005 and 0.000 respectively. These results are consistent with other research findings such as by Setegn et al. (2013), Magutu et al. (2010) and He (2009). This finding concluded that the business process reengineering can raise or increase quality as well as the productivity. However, the results showed that the personal gain after business process reengineering has not a significant influence on organisational performance, which recorded a value of 0.516 .

\section{Conclusion and Recommendations}

This study investigated the business process reengineering factors impacting on organisational performance by focusing on employees at a Riyadh factory for re-refining oils. The results showed that the only two factors out of three being investigated actually do affect organisational performance in the Riyadh factory, namely 1) major improvements after business process reengineering and 2) the major changes after implementation of business process reengineering. It also can be conclude that there is a significant and positive relationship between major improvements after business process reengineering and organisational performance. However, there is a significant and negative linkage between major changes after implementation of business process reengineering and organisational performance. Interested parties and future study directions can further develop model with the same variables in different sectors such as telecommunication, services, and financial sectors rather than focusing on the industrial sector. In addition, future studies could also include some other factors of BPR that could influence organisational performance.

\section{References}

Al-Mashari, M., \& Zairi, M. (2001). Revisiting BPR: A holistic review of practice and development. Business Process Management, 6(1), $10-42$. 
Chase, R. B., Jacobs, F. R., Aquilano, N. J., \& Agarwal, N. K. (2006). Operations management for competitive advantage (11th ed). New York: McGraw-Hill Publishing Company Limited.

Eke, G., \& Achilike, A. (2014). Business process reengineering and organisational performance in the Nigerian Banking sector. Academic Journal of Interdisciplinary Studies, 3(5), 113-123.

Gouranourimi, F. (2012). Total quality management, business process reengineering and integrating them for organisations' improvement. American Journal of Scientific Research, 47-59.

Grover, V., Jeong, S. R., Kettinger, W. J., \& Teng, J. T. C. (1995). The implementation of business process re-engineering'. Journal of Management Information Systems, 12(1), 109-144.

Habib, N. M. (2013). Understanding critical success and failure factors of business process reengineering. International Review of Management and Business Research, 2(1), 1-10.

Hall, G., Rosenthal, J., Wade, J. (1993). How to make reengineering really work. Harvard Business Review, 71(6), 119-131.

Hassan, M., Mukhtar, A., Qureshi, S., \& Sharif, S. (2012). Impact of TQM practices on firm's performance of Pakistan's manufacturing organisations. International Journal of Academic Research in Business and Social Science, 2(10), 232-259.

He, X. J. (2009). Factors affecting business process reengineering in China. International Journal of Internet and Enterprise Management, 7(2), 172-196.

Johnson, G., Scholes, K., \& Whittington, R. (2006). Exploring corporate strategy, texts and cases (7th Enhanced Media Edition), Prentice Hall Inc.

Magutu, P. O., Nyamwange, S. O., \& Kaptoge, G. K. (2010). Business process reengineering for competitive advantage; Key factors that may lead to the success or failure of the BPR implementation (The Wrigley Company). African Journal of Business \& Management, 1, 135-150.

Mansar, L, S., \& Reijers, A, H. (2007). Best practices in business process redesign: Use and impact. Business Process Management Journal, 13(2), 193-213.

Mohammad, M, M., \& Elaheh, M. (2014). The effect of business process re-engineering factors on organisational agility using path analysis: Case study of ports \& maritime organization in Iran. Asian Economic and Financial Review, 4(12), 1849-1864.

Randle, W. M. (1995). Delivering the future: Redefining the role of banks in new competitive environment. Bank Management, 71(1), 45-48. 
Setegn, D., Ensermu, M., \& Moorthy, P. K. (2013). Assessing the effect of business process reengineering on organizational performance: A case study of Bureau of Finance and Economic Development (BOFED), Oromia Regional State, Ethiopia. Researchers World: Journal of Arts, Science, and Commerce, 4(1), 115-123.

Sidikat, A., Ayanda, A. M. (2008). Impact assessment of business process reengineering on organizational performance. European Journal of Social Sciences, 7(1), 115-125. 